\title{
A imagem visual Descoberta, conquista e museificação da América (séculos XVI e XVII)
}

ANA CRISTINA GUILHOTTI

ANA CRISTINA GUILHOTTI é historiadora do Museu Paulista da Universidade de São Paulo.

Agradecemos à prota Sonia Ferraro Dorta por informaçōes bibliográficas sobre as sociedades indigenas brasileiras.

R. E. Alegria, Las Primeras Repre sentaciones Gráficas del Indio Americano 1493-1523, Puerto Rico. Institutode Cultura Puertorriqueña, 1978, p. 17.

2 O material iconográfico europeu sobre a América e bibliografia sobre este tema encontram-se reunidos em obras como: $F$. Chiapell (ed.). First Images of America: The Impact of the New World on the Old, Berkeley, Los Angeles, Londres, 1976. 2 vols.: Catalogue The European Vision of America, Cleveland, The Cleveland Museum of Art, 1976 e Katalog - Mythen der Neven Welt, Berlim, 1982; G. Therien, Les Figures de I'Indien, Montreal, Université du Québec à Montréal, 1988, etc.

3 G. Chinard, L'Exotisme Américain, Paris, s. 1., 1911, p. 57.

4 B. Bucher, La Sauvage aux Seins Pendants, Paris, Hermann, 1977. p. 6.

5 Chinard, op. cit., p. 77 .
Levou muito tempo até os conquistadores europeus da América entenderem o que haviam encontrado, se é que jamais o fizeram. A necessidade de classificar e ordenar o diverso americano incitou-os a produzir inúmeros discursos: uma extensa literatura de viagens e uma significativa iconografia sobre esse Mundus Novus.

Na realidade, a América que se desvenda aos olhos dos europeus transforma-se, quase que imediatamente após sua descoberta, em tema iconográfico: em 1493. realizam-se gravuras para ilustrar a carta de Colombo, na sua edição latina, publicada em Basiléia(1). No longo do século XVI, a Europa produz gravuras, ilustraçōes, pinturas e material cartográfico, onde se elabora uma abundante imagística do continente americano.

Esta documentação européia constitui-se, fundamentalmente, das gravuras e ilustrações que integram os relatos de viagens, diários de bordo e crônicas sobre o Novo Mundo. Compōe dois conjuntos: imagens originais e reproduçōes.

Deve-se ainda mencionar a cartografia, cujas representações figurativas persistiram muito além do limiar renascentista As figuras destes mapas traduzem, em termos visuais, uma concepçāo de mundo bem definida que evoca o ambiente natural e humano americano.

Numa escala progressiva, os elementos do universo americano também integraram as representaçōes pictóricas da Europa. Os pintores produziram e reproduziram inúmeras formas, elaborando, muito lentamente, um repertório da fauna, flora e dos aborígines da América, para a pintura européia(2).

A quase totalidade das imagens européias sobre a terra descoberta será confeccionada na Europa, no momento de impressão dos textos que elas irão ilustrar. Os gravuristas irão ouvir e/ou ler os relatos de viagens para elaborar suas representaçōes visuais. Em 1575, para a publicaçāo da Cosmographie Universelle em Paris, André Thevet afirma ter trazido de Flandres os melhores gravadores para ilustrar sua obra, embora também mencione ter-lhes fornecido alguns esboços e crayons (3). Em alguns casos, foram utilizados modelos naturais. Os desenhos do alemão Christoph Weiditz, realizados em 1529 , tinham por tema os aborígines que ele viu na Espanha, na corte de Carlos V, e que foram presentes de Cortés ao rei(4)

Faltam referências sobre alguma preocupação em se levarem desenhistas a bordo dos navios que partiam para o Novo Mundo, durante o século XVI, para a função paralela à dos escrivães. Parece que, se algumas imagens são realizadas in loco, é porque um tripulante, soldado ou marinheiro, possuía dotes artísticos para retratar a paisagem descoberta. Este é o caso das gravuras que aparecem na obra de Jean de Léry. Em sua primeira edição, em 1578, são mostradas cinco pranchas que o autor afirma terem sido executadas por um marinheiro, sob a sua orientação(5)

As reciclagens sofridas pelas imagens da América, através da reprodução desta iconografia, ainda no século XVI, testemunham o interesse da Europa por seu Novo Mundo. Nesse sentido, a obra de A. Thevet é significativa. O Retrato do Cacique Ouoniambec aparece, pela primeira vez, em 1558, em Les Singularitez de la France Antarctique, ilustrará, em 1575, a Cosmographie Universelle; e, em seguida, em 

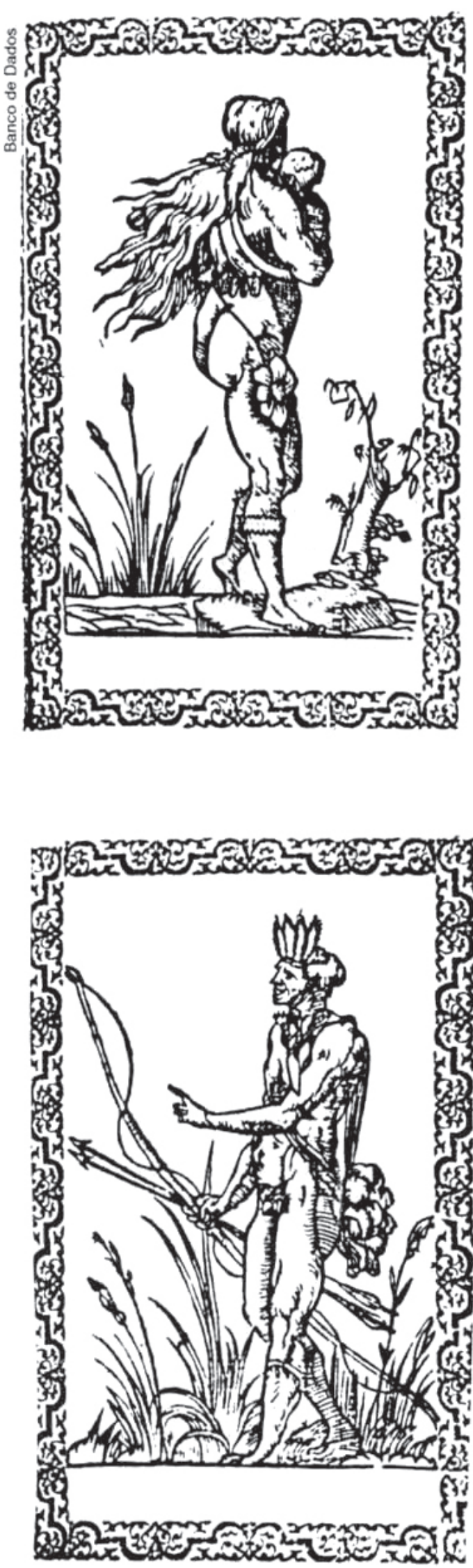

A brasileira e o brasileiro; gravuras do livro de I. Sluperij, Omnium Fere Gentim, segunda metade do séc. XVI
1584, será reproduzido em Vrais Pourtraits. Thevet refere-se a esta última reprodução como diferindo " um pouco" da anterior(6). Também, o retrato de Montezuma, colocado no Vrais Pourtraits, foi inspirado numa imagem deste rei asteca localizada no Codex Mendoza (ca. 1541-1542), obra que pertenceu a Thevet. Na imagem reciclada, o rei aparece com um diadema cujas penas não existiam na figura do Codex (7).

Muitas das obras sobre o Novo Mundo alcançaram sucesso imediato, como o livro de Hans Staden, publicado em 1557, que obteve quatro ediçōes em um ano, ou a obra de Theodor de Bry, Grands Voyages, editada, simultaneamente, em latim e alemão, e publicada em 13 volumes, entre 1590 e 1634 , tendo atingido um largo público(8) .

Os leitores destas obras e, portanto, fruidores das imagens que circulavam reproduzidas em xilogravuras, até meados do século XVI, e depois em calcografias e águas-fortes, encontravam-se, principalmente, entre a aristocracia européia e a classe de comerciantes e navegadores que buscavam informaçōes sobre a América, seja por interesses econômicos, políticos ou diletantismo(9) .

Em relação aos meios mais modestos, num contexto de alfabetização muito parcial da sociedade européia, as ilustraçôes que ornavam os livros sobre o mundo novo atingiram uma vasta categoria de compradores, tâo curiosos quanto o populacho de Sevilha e Barcelona, que correu às ruas para ver os "seres" americanos, trazidos por Colombo, em sua primeira viagem(10)

Um estudo dessa América descoberta, através de suas imagens realizadas pelo
6 Idem, ibidem, p. 58

7 C. F. Feet, "Vienna's Mexican Treasures: Aztec, Mixtec and Tarascan Works from 16th Century Austrian Collections", in Archiv für Volkerkunde, Bd. 44, 1990, p. 14.

8 Bucher, op. cit., p. 13.

9 Idem, ibidem, p. 14.

10 M. C. Garcia Saiz, La Imagen del Indio en el Arte Español del Siglo do Oro, Sevilla, s.1., 1990, p. 419. 


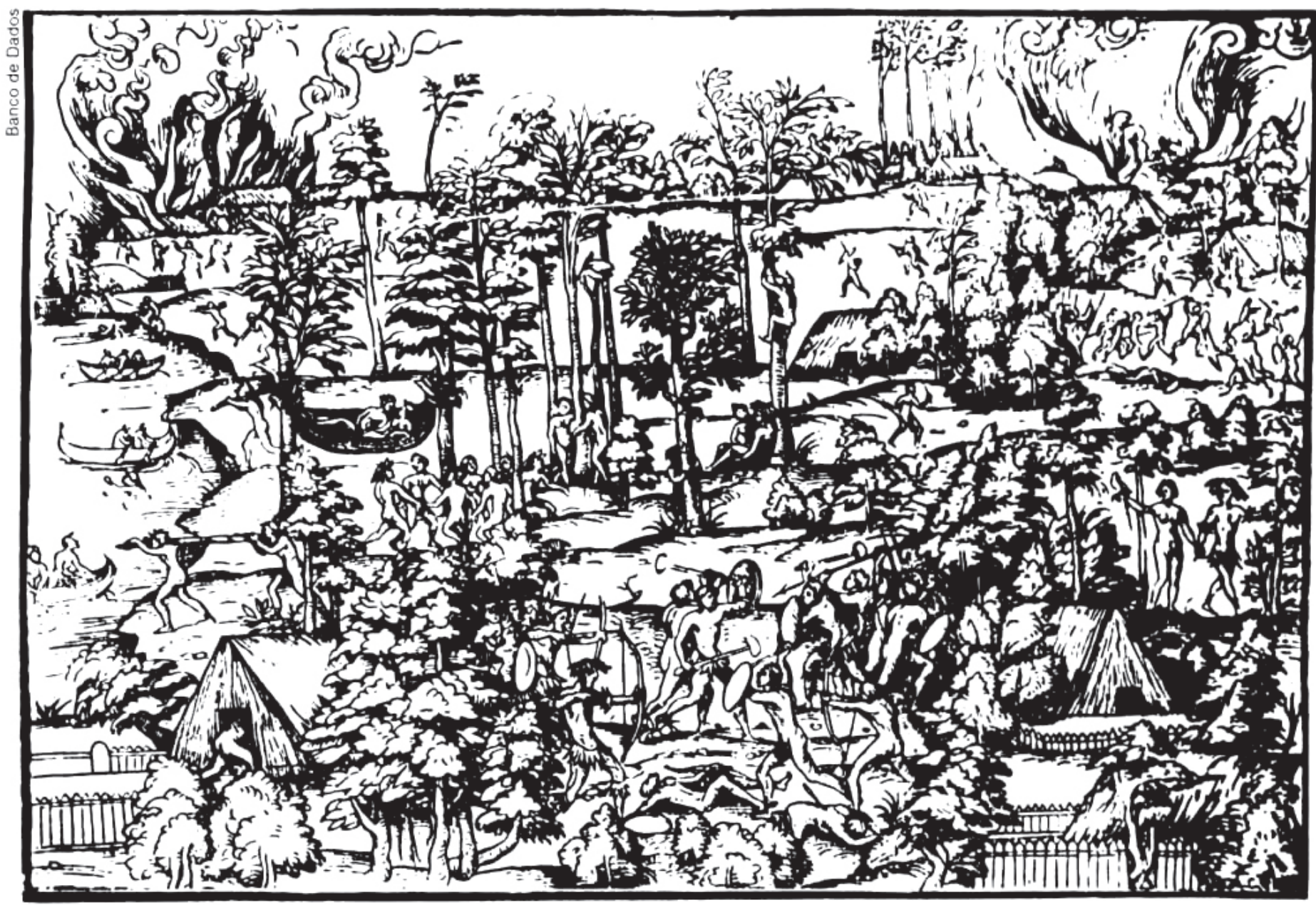

Gravura do livro Une Fête Brésilienne - c'est la Deduction du Dumptueux Ordre..., Rouen, 1551 (a tradução literal seria "Uma Festa Brasileira - é a Deduçảo da Suntuosa Ordem")

11 F. Denis, Une tête brésilienne cé lébrée a Rouen en 1550 - suivie d'un tragment au XVle siècle rou lant sur la théogonie des anciens peuples du Brésil et des poèsies en langue tupique de Christovan Valente, Paris, J. Techener, 1850. pp. 20-1. europeu, por sua complexidade não caberia aqui. Assim, para ressaltar alguns pontos básicos, optamos por tomar uma imagem do século XVI, que condensa atributos essenciais dessa construção imaginária do Novo Mundo e, para confronto, outra, do século XVII, que revela a institucionalização desse imaginário.

A primeira imagem (figura 1) é de autor desconhecido e foi realizada para ilustrar o relato da festa brasileira que celebrava a entrada triunfal do rei Henrique II e da rainha Catarina de Médicis, em Rouen, em outubro de 1550 . O livro, intitulado Une fête brésiltenne - C'est la deduction du sumptueux ordre platsantz spectacles et magnifiques théatres, et exhibes par les citoiens de Rouen..., foi publicado em Rouen, em 1551. Segundo Ferdinand Denis, os autores deste relato teriam sido, muito provavelmente, Maurice Scève e Claude de Taillemont, dois poetas que já haviam relatado as festas de Lyon, em 1548. Mas também aponta Claude Chapuis, que foi encarregado de um discurso a Henrique II, e Du Tillet, escrivão da corte e autor do relato da entrada real em Paris, em 1549, como outros possíveis autores para a famosa obra de Rouen(11)

$O$ livro de $\mathrm{F}$. Denis fala de cerca de trezentos figurantes, entre cinqüenta autênticos tupinambás levados do Brasil à França, além de marinheiros normandos e prostitutas, que vão representar cenas transcorridas na América. Cabanas indígenas serāo pintadas, papagaios e macacos se soltarāo pelas árvores. A gravura a que nos referimos representará esta América " transportada" para a Europa

Ela contém chaves importantes para entendermos o processo de codificação a que foi submetido o mundo descoberto, para ser ordenado. Um primeiro exame permite perceber que esta imagem é produto da reunião de várias cenas independentes. Cenas que, por sua vez, se interpenetram, resultando em agrupamentos fluidos. Para facilitar a descrição, distinguiremos três faixas horizontais, mais ou menos paralelas. Dessa forma, da esquerda para a direita e de baixo para cima, representa-se, na primeira faixa, um aborígine entrando em uma cabana de palha 
rodeada por uma profusa vegetação e cercas de madeira; na cena seguinte, outros aborígines lutam entre si em uma clareira; na última cena, um outro choupo aparece cercado de árvores e paliçada (a proximidade desta habitação com um casal de mãos dadas permite a constituição de uma única cena). Na segunda faixa, destacam-se canoas dirigindo-se para uma praia enquanto algumas personagens carregam troncos de madeira, com certeza pau-brasil. A seguir, vem a cena que representa um casal na rede, além de um grupo que de mãos dadas parece "brincar de roda" em torno a uma árvore; também ocorrem casais sentados debaixo de árvores ou nelas apoiados. Um aborígine abraçado, no alto, a um tronco, colhe seus frutos. No extremo da faixa, rodeado por uma abundante vegetação, um casal caminha de mãos dadas (no braço estendido da mulher está pousada uma ave, provavelmente uma arara). Na terceira faixa, estão algumas cabanas incendiadas, dando-se grande destaque para as labaredas que sobressaem $\mathrm{cm}$ ambos os cantos da imagem. Ao lado direito, novamente, aparece luta entre indígenas. No centro da faixa, evidencia-se uma profusão de folhagens de várias espécies vegetais.

Esta descrição sumária permite perceber que o denominador comum a todos os conjuntos é a figura do indígena. Nas várias representações não se diferenciam seus corpos e fisionomias (estes sofrem, somente, uma modificação na escala do desenho). Assim, estas figuras são diversificadas por seus movimentos, seus gestos e seus agrupamentos.

Portanto, é coerente pensar que a codificação das açōes tipificadoras do homem americano possam servir de fio condutor para o estabelecimento da diferença $\mathrm{e}$, assim, abrir caminho para a conquista desse mundo e sua incorporação à Europa.

Uma das cenas que representa a guerra vai-se destacar de todas as outras. Colocada na parte central do primeiro plano da imagem, as personagens aí desenhadas alcançam a maior escala utilizada na representação humana, nesta gravura: alguns aborígines possuem altura superior a da cabana, localizada no lado direito. A imagem nos mostra a preocupação com detalhes como a figuração das armas indigenas: tacapes, escudos, arcos e flechas e a caracterização dos combatentes: pode-se supor duas naçōes inimigas, uma representada pela nudez total e outra pelo porte de cocares, saiotes, braçadeiras e joelheiras de penas. Mas a atenção é, primeiramente, tomada pelo desenho dos corpos delineando os movimentos de cada guerreiro, os gestos da luta. A morte, conseqüencia natural das guerras, está presente nos dois homens estirados no chão $\mathrm{e}$ potencializa $\mathrm{O}$ ato agressor.

A representação da guerra irá repetir-se no canto superior direito. Desta vez, a cena de combate ganhará outro elemento para reforçar a violência: as cabanas incendiadas. Também ao lado esquerdo, as grandes labaredas que se erguem das habitaçōes podem ser resultantes de outros episódios belicosos.

Ressaltar a figura do guerreiro e de elementos que denunciam a presença da luta parece querer indicar-nos que a guerra constitui uma forma patologicamente endêmica do relacionamento indígena na América(12). O homem americano não co. nheceria outra maneira de " resolver" problemas: ele destrói aquele que o incomoda. A gravura de Rouen mostra que não há intermediação quando " uma casta de gentiơ" está diante da outra. Gente bárbara que desconhece qualquer tentativa de entendimento por parte de chefes, de representantes. Pelo contrário, nenhuma personagem dá pistas de uma hierarquia social ou se refere a formas de organizaçāo política definidas.

Estas consideraçōes remetem-nos àqueles valores negativos que, segundo Georg Thomas, tiveram influência decisiva na elaboração da imagem do indígena pelos europeus, ao entrarem em contato com as terras brasileiras(13). O autor destaca a antropofagia como a característica que mais marcou o juízo sobre a América. Dificilmente esta ação poderia ser representada na festa de Rouen, mas foi largamente retratada pela iconografia européia e aparece em nossa gravura do século XVII $(f i$ gura 2). A seguir, viria a inimizade contínua das tribos entre si, que " parecia aos brancos expressão última do caráter de degeneraçãơ". Gandavo, aliás, tem uma definição clara sobre esta característica: "Nunca se acha neles paz nem é possível haver entre eles amizade, porque umas naçōes pelejam contra outras e matam-se muitos deles, e assim vai crescendo o ódio cada vez mais e ficam inimigos verdadeiros perpetuamente". E, por último, a falta total de instituições sociais, jurídicas e políticas na cultura indígena. Também Gandavo nota que na língua indígena não existe nem $F$, nem $L$, nem $R$ : isto significava que eles nẩo tinham nem $F e ́$, nem Lei, nem Rei(14).
12 M. C. Cunha, "Imagens do Indios do Brasil: O Século XVI", in Estu. dos Avançados, 4(10), pp. 91-110. Ao analisar a questâo da antropofagia a autora também menciona as guerras incessantes nas sociedades indigenas brasileiras.

13 O. Thomas, Pollitica Indigenista dos Portugueses no Brasil 1500-1640 (trad. bras. de S. J. Jesús Hortal), Sâo Paulo, Ed. Loyola, 1981. pp. 20 e segs.

14 P. M. Gandavo, Tratado da Terra do Brasil, introd. de Capistrano de Abreu, Belo Horizonte, Ed, Itatiaia; Sảo Paulo. Ed. da Univorsidade de Sáo Paulo, 1980, p. 54 
15 J. Delumeau, A Civilizaçào do Re nascimento, Lisboa, Ed. Estampa. 1984, vol. I. p. 51, explorando idéia de Le Goff.

16 F. Fernandes, Organizaçáo Social dos Tupinambá, São Paulo, Difusáo Européia do Livro, 1963. A refe réncia leita no texto à sociedade indigena americana foi desenvolvida nesta obra.

17 F. Affergan, Exotisme ef Altérite, Paris, Presses Universitaires de France, 1987, p. 27

18 Fernandes, op. cit, nota 15

19 C. Ginzburg. "Ticiano, Ovidio e os Códigos da Figuração Erótica no Seculo XVI", in Mitos, Emble mas a Sinais, Sáo Paulo, Compa nhia das Letras. 1989
A imagem de Rouen insere o homem americano na dimensão primitiva daqueles que não fazem parte do orbis christianus, dimensão onde a concepção de " nature$z^{\prime \prime}$ é aplicada às relações humanas. Gente que anda nua, adornada com penas, que porta arco e flecha, que pratica açōes indiscriminadas de guerra e expōe, publicamente, seus atos de afeto; gente que nada domestica e não é domesticada.

As cenas que expressam a dimensảo afetiva da vida indígena representam, com clareza, homens e mulheres, em escala ligeiramente menor do que a dos guerreiros. Os atos de afeto são veiculados por uma série de cenas que retratam a gama de açōes envolvidas. O casal na rede oferece lembrança imediata do ato sexual, enquanto que o casal encostado à árvore e o outro sentado sob ela, assim como o par que caminha de mãos dadas, representam outras variantes dos atos amorosos. A América ainda vive em um estado natural, desconhecendo regras, permitindo a ação instintiva: o pudor e o pecado, tão conhecidos dos conquistadores cristâos, estẩo ausentes.

Estas representações possibilitam aos europeus do século XVI visualizarem, neste Mundus Novus, um lugar de realização para seus desejos, recalcados na Europa cristã, de uma vida sexual mais livre(15). Esta idéia é reforçada pela imagem da muther indígena que somente aparece participando dos atos afetivos, representação que omite todas as várias atividades femininas resultantes da divisão sexual do trabalho(16).

Torna-se interessante observar como é ambíguo para a Europa esse estado natural em que se encontra a América, ou seja, o ato primitivo americano: ora negativo, representado pela violência endêmica da guerra, pela ausência de qualquer instituiçāo reguladora da sociedade, ora positivo, expressado através da " naturalidade" dos atos amorosos enquanto promessa de disponibilidade feminina. Neste contexto, ressalta-se a observaçâo de Francis Affergan de que os predicados analíticos atribuídos à alteridade (lembremos que o outro americano é inédito, por excelência, para o europeu) constituem " qualidades necessariamente ambivalentes, pois se ignoram a origem e essência do sujeito" (17).

Também, numa perspectiva ambígua, o conquistador localiza a atividade econômica do indígena. A única cena de atividade econômica "autenticamente" americana é a coleta de frutos. Já os do aborígines que carregam um grande tronco de madeira aos ombros foram desenhados em uma escala um pouco menor que a traçada para o casal de mãos dadas. Em uma seqüência ascendente, encontram-se outras quatro representaçōes do mesmo ato (notemos que a reduçăo das formas é feita de forma gradual, da primeira à quinta figura, mantendo-se os movimentos do transportador)

Esta ênfase num aspecto muito particular da vida econômica européia, transferida aos americanos, expressa, num plano simbólico, a possibilidade de o europeu enriquecer-se na exploração das novas terras, comercializando pau-brasil na Europa e utilizando a força de trabalho indigena.

Nas várias cenas que compōem a imagem de Rouen, estão ausentes os europeus ou qualquer traço material de sua civilização. A Europa, todavia, está presente, e de forma marcante. Com efeito, o fluxo ininterrupto do transporte de pau-brasil remete ao processo de acumulação de mercadorias numa Europa iminentemente capitalista. Por outro lado, a rede fora da habitação (onde o envolvimento amoroso dos tupinambás se realizava veladamente), presa entre árvores, é projeção européia, assim como os bucólicos passeios dos indígenas, de mãos dadas por entre as árvores (18) . Além disso, as representaçōes dos quatro casais derivam de arquétipos visuais europeus, bastante correntes, em que o protagonista masculino, à frente, conduz sempre a mulher. Carlo Ginzburg, estudando os códigos de figuração erótica do século XVI, estabeleceu, para a destinação de tais imagens, o público masculino europeu(19) .

Este painel de atos e gestos do homem americano, em que a alteridade é corrompida pelo olhar do observador, acumula atributos que procuram apresentar uma síntese da vida indigena. Esta preenche todo o espaço pictórico. As cenas têm limites arbitrários e flexíveis e parecem expandir-se para além da imagem. Elabora-se, portanto, a idéia de uma América praticamente toda habitada. Atributo tranqüilizador para o descobridor: ele poderá caminhar pelas mesmas trilhas. Se a vegetação está também onipresente, não domina o homem, nem o atemoriza. Não há nada que possa, nela, marcar o tropicalismo como diferença. O reino animal está minimamente presente, reduzido à figura exótica da arara.

Assim, pela gravura de Rouen, cenas concomitantes, ações paradigmáticas, constituem juntas uma totalidade atribuída ao universo americano; cenas reunidas para 


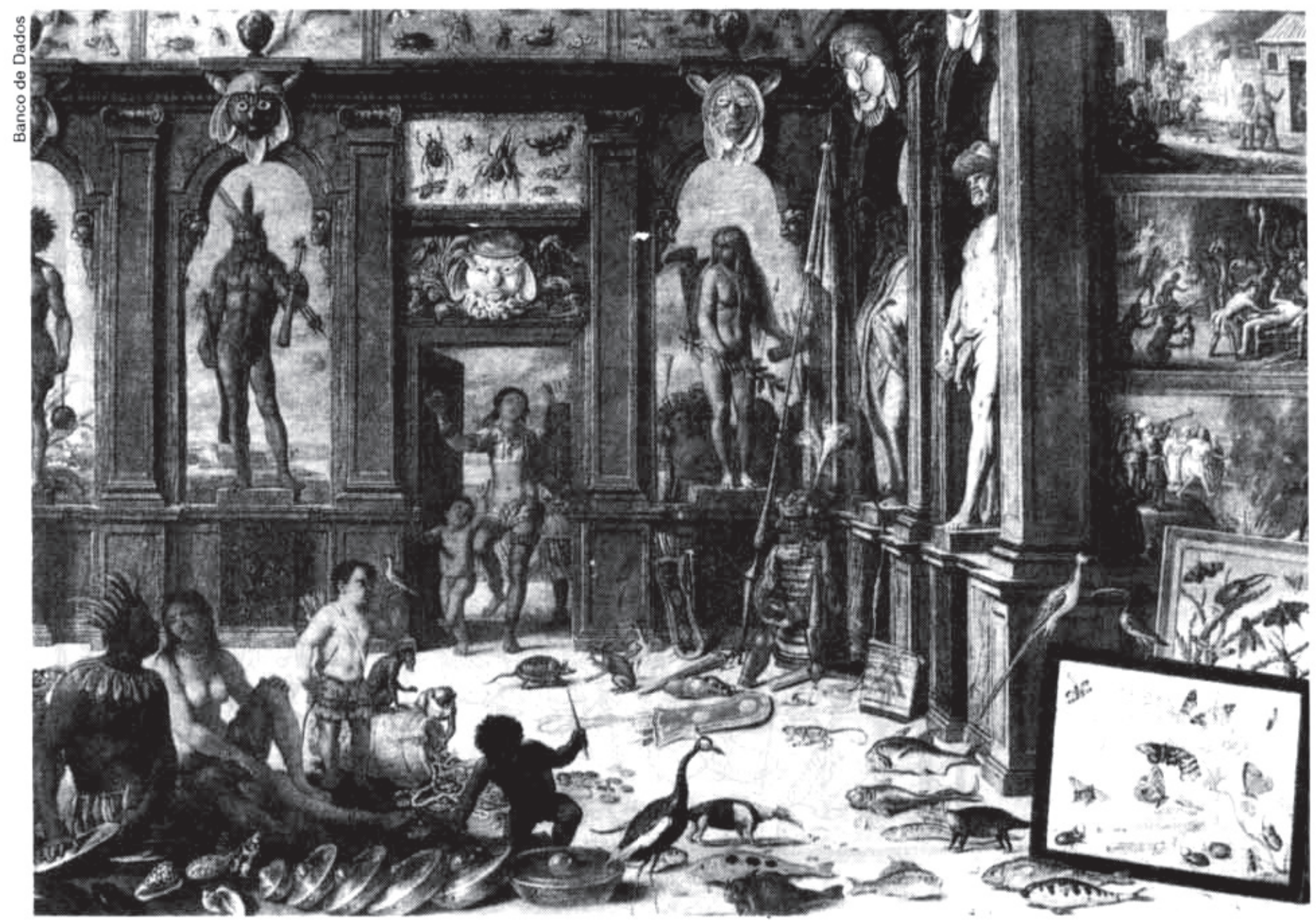

elaborar uma imagem da América descoberta que logo se transformará em imagem da América conquistada.

Ir "até onde o mundo alcança" como enuncia a divisa "Qua patet orbis" do Conde Maurício de Nassau, designado " príncipe humanista do Novo Mundo", mostra a amplitude de um desejo de totalidade, de universalidade. Estamos, pois, dentro dos mesmos parâmetros que os gabinetes de curiosidades e as Kunstkammerns dos séculos XVI e XVII. Krzysztof Pomian os estudou por meio das pinturas contemporâneas que descortinam seus interiores e ilustram " as grandes categorias de seres e de coisas que, em conjunto, esgotam o conteúdo do universo: o sagrado e o profano, o natural e o artificial, o animado e o inanimado, o próximo e o distante, etc." (20). Estas coleções, já enquanto bens patrimoniais, objetos possuídos por alguém, constituem um " universo aprisionado" . Na realidade, a totalidade que elas permitem alcançar é problemática, pois consiste na reunião de fragmentos selecionados ou possíveis de obter, exempla do universo referido.

Uma rápida busca pelos gabinetes de curiosidades europeus permite identificar objetos provenientes da América, em Viena, Bolonha, Praga, Copenhague, Uppsala, e também na Holanda e na Inglaterra. O inventário do Gabinete de Antonio Gigante (1535-98), localizado em Bolonha, é bom exemplo das disparidades no interior das coleções: inclui no seu acervo etnográfico das Índias Ocidentais um mapa pré-colombiano, consistindo em duas partes de um Codex, dois cocares de penas da Flórida; nove ídolos de pedra "do Novo Mundo"; um machado de pedra; " uma faca de pedra com o cabo de madeira com a qual eles sacrificavam" ; uma série de arcos, flechas e pedras (utilizadas como instrumentos cortantes); um mosaico de penas e uma mitra mexicanos(21).

Durante o século XVI e até meados do século XVII, a América é introduzida nos
Americque, óleo sobre tela de Jan Van Kessel, Antuérpia, 1666

20 K. Pornian, "La Culture de la Cu. riosité", in Le Temps de la Refle xion, III, Paris, Gallimard, 1982, p 342.

21 O. Impey e A. Macgregor (eds.) The Origins of Museuns - The Ca binet of Curiosities in Sixteenth an Seventeenth Century in Europe, Oxford, Clarendon Press, 1985. Os vários artigos que compôem esta obra citam a presença de objetos americanos nos gabinetes distribuidos pela Europa. Sobre o inventário de Antonio Gigante, veja p. 18. 


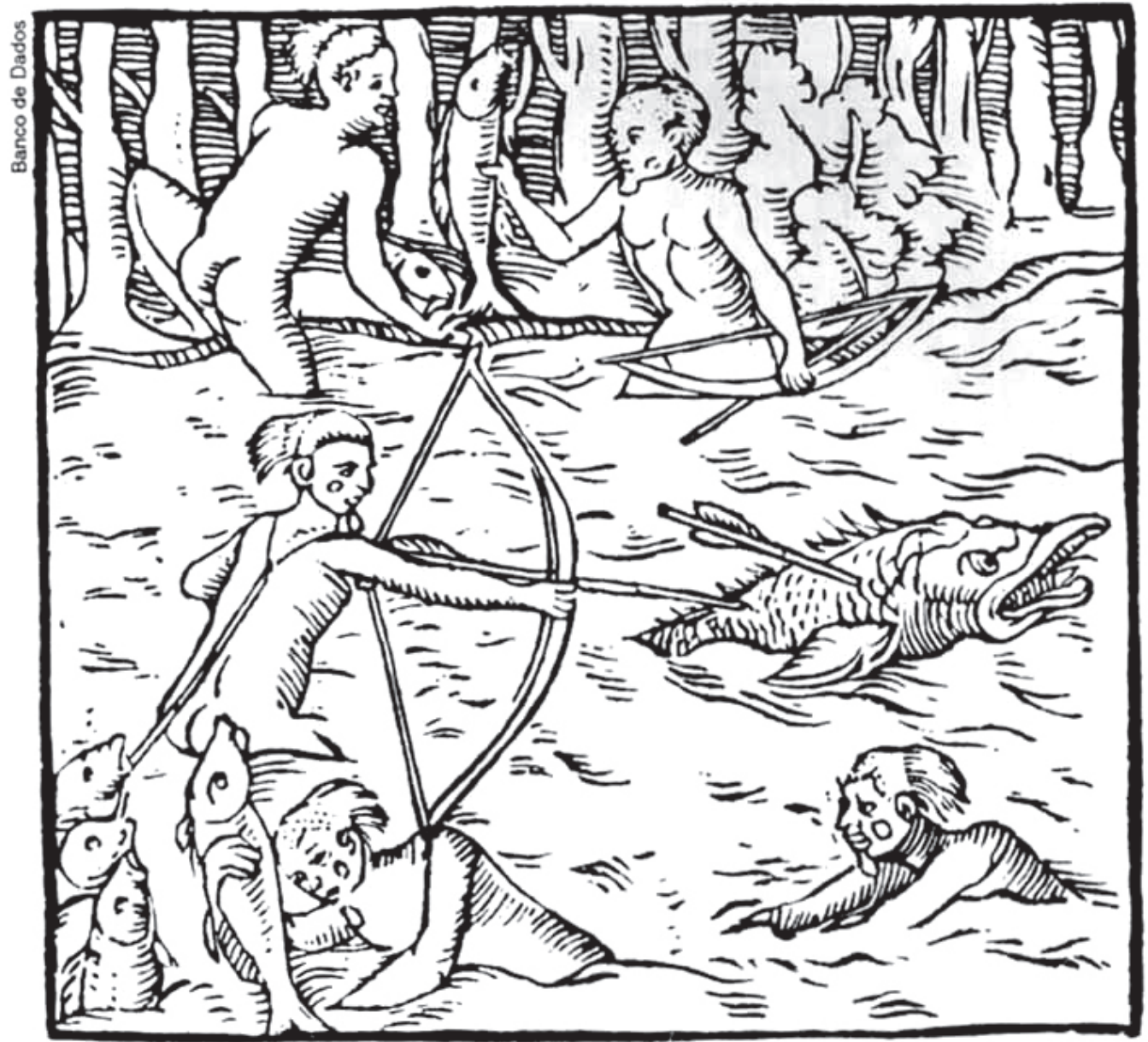

gabinetes de curiosidades de forma fragmentária, sintetizada, principalmente, pela cultura material. No entanto, pela imagem é possível superar as limitaçôes dos gabinetes.

A figura 2, datada de 1666, é um componente do famoso tema alegórico da iconografia européia, muito em moda na segunda metade do século XVI e no século seguinte, relativo às Quatro Partes do Mundo. Geralmente, simbolizadas por figuras femininas, desta vez, pela obra do "Kleinmeister" de Antuérpia Jan Van Kessel (1626-79), cada parte será representada por um painel central $(48,5 \times 67,5 \mathrm{~cm}) \mathrm{cer}$ cado por dezesseis painéis pequenos $(14,5 \times 21,0 \mathrm{~cm})$. São pinturas a óleo sobre cobre e nos interessa o quadro cujo título é Americque (22).

P. Whitehead e J. P. Boeseman, que estudaram esta imagem no quadro da produção artística referente ao Brasil, realizada na administração de Nassau, encontraram " modelos americanos" tanto para as figuras humanas quanto para a exube-

22 P. Whitehead e M. Boesernan, Um Retrato do Brasil Holandés do Sé culo XVII: Animais, Plantas a Gen tes pelos Attistas de Johan Maurits de Nassau (trad. bras. Edmond Jorge), Rio de Janeiro. Livraria Kosmos Editora, 1989, p. 90.

23 Idern, ibidem, pp. 90-4.

24 Idem, ibidem, p. 92.

25 As imagens que ilustram a obra de Hans Staden (1557). Jean de Léry (1578). Theodor de Bry (1590-1634), citando apenas algumas das mais famosas, sáo um bom exemplo da recortência às cenas de canibalismo na iconografia européia sobre o Novo Mundo. dos séculos XVI e XVII. rante mostra da fauna do Novo Mundo representadas na pintura de Van Kessel(23).

Os dois aborígines colocados nos nichos, nas extremidades da sala, foram inspirados nas pinturas dos índios tapuias realizadas por Albert Eckhout(24). O homem porta um cocar de penas, na mão direita segura quatro dardos e um propulsor e na outra, um bastão. A mulher tem uma mão abaixada, segurando um ramo à sua frente, numa atitude de modéstia. Na cesta, pendurada em seu ombro, traz um pé e, na outra mão, segura um braço e mão humanos: elementos que denunciam a prática do canibalismo pelos aborígines americanos cujas cenas repugnaram os europeus, mas que foram amplamente representadas pela iconografia dos séculos XVI e XVII(25). O nicho da extrema esquerda mostra um homem de cocar e saia de penas segurando boleadeiras, fazendo-nos pensar em culturas meridionais do continente.

Um grupo, no canto esquerdo da imagem, traz um negro africano com cocar, colar e saia de penas, que segura um instrumento musical (um gongo gamelano javanês). A seu lado, senta-se a mulher americana que the dirige o olhar: brincos, colar e pulseiras adornam-lhe o corpo. As crianças também estāo presentes: um filho da América e outro da África. Assim, Van Kessel apresenta toda a diversidade do 


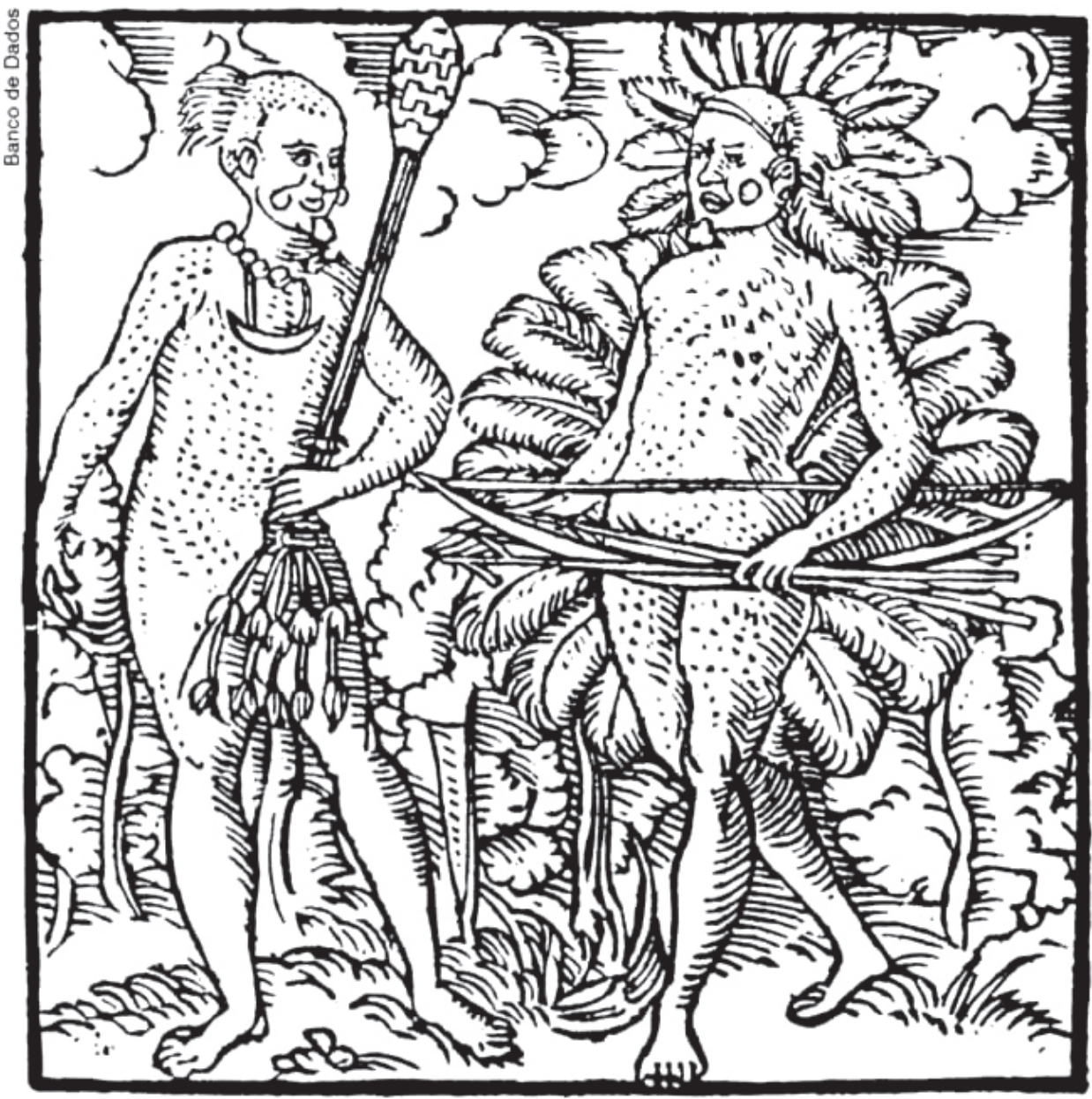

aborígine americano, de sexo e idade: homem e mulher, adulto e criança. Nos nichos da direita, aparecem duas estátuas de brâmanes cujos modelos, provavelmente, se originaram do Itinerario voyage ofte schipvaert naar Cost ofte Portugaels Indien: 1579-1592 (1596), como indicam Whitehead e Boeseman (26). Passando atrás do nicho aberto à direita e encaminhando-se para a porta, segue um grupo de asiáticos, precedido por aborígines americanos, enquanto que uma mulher asiática e uma criança entram dançando pela porta. No plano de fundo à direita, estão algumas armaduras e armas japonesas. Os elementos das regiōes distantes e maravilhosas, portanto exóticas para o homem da Europa moderna, adquirem aqui a plenitude destas qualidades atribuídas às suas terras nativas. Parece, no entanto, que para o pintor o exotismo da quarta parte do mundo excede ao de qualquer outra: a América recebe a África e a Ásia.

A iconografia, portanto, vai introduzir, nos gabinetes de curiosidades, o elemento americano que thes faltava: os próprios habitantes humanos, colocados nos nichos que estavam vazios, como estátuas, ou então, vivos, em vários espaços, entre uma profusa confusão de diversos objetos. O pintor direciona o olhar do espectador para os corpos indígenas que, na realidade, hierarquizam a cena.

Já não se trata mais de elaborar uma imagem da América, que se preocupe em multiplicar os atos do homem das novas terras, como fez a iconografia quinhentista. Importa, agora, selecionar e hierarquizar o material americano - os corpos indigenas, a diversidade da fauna e, com menos importância, a cultura material - que deverão dar-se ao olhar da Europa para serem apreciados, guardados, inventariados e, mais tarde, estudados. Encerrados em salas de habitaçōes principescas, estes referenciais iräo impor-se como padrões, estereótipos, dos elementos constitutivos do Novo Mundo, no momento de seu descobrimento. A pintura de Van Kessel, como uma porta aberta em uma parede, permite que visitemos este recinto onde se conquista, totalmente, embora num plano alegórico, aquele Mundus Novus. Dessa forma, totalizada dentro de um gabinete de curiosidades, a América adquire uma imagem metaforicamente cristalizada, mais precisamente, uma imagem museificada.
Na página à esquerda, indios pescando com flechas; ao lado, dois cheles tupinambás; ambas as gravuras estáo na obra de Hans Staden, publicada na Alemanha em 1557 